\section{Dansk/Svensk Venskabs- og Kulturfonds kulturpris 1998}

Takketale ved modtagelsen af prisen

2. september 1998

Af oversætteren Anne Marie Bjerg

$\mathrm{E}$

gentlig var det min første svenske oversættelse - af Per Wästbergs Luftburen/Lufthavet - som lokkede mig til Stockholm. Byens geografi havde jeg lært grundigt at kende gennem romanen, jeg havde aldrig været der, der måtte jeg hen. Det kom jeg - og blev der i syv år. Det er en anden historie som ikke skal fortælles her. Men den rejse kom der altså kærlighed og litteratur ud af og mange rejser mellem Danmark og Sverige.

I løbet af de syv år jeg boede i Stockholm, lærte jeg det svenske samfund at kende, på svenske betingelser, og det var slet ikke som jeg troede: ligesom Danmark, bare lidt bedre. Det kunne være barsk indtil det middelalderlige, bureaukratisk indtil det surrelistiske. $\mathrm{Og}$ smukt og storslået og generøst. Men absolut ikke for sarte sjæle. Frem for alt var det fremmed! Selv om der gik en rum tid inden jeg for alvor opdagede hvor fremmed. Intet, absolut intet, var som derhjemme. Og den overfladiske lighed mellem de to sprog, svensk og dansk, er - som vi alle ved - meget bedragerisk.

Den metamorfose jeg gennemgik i de syv år hvor jeg prøvede at blive svensker, først og fremmest ved at lære at tale og skrive sproget - læse det kunne jeg i forvejen - kender enhver emi-og immigrant: den gradvise ændring af ens personlighed $i$ og med at man sanser og erfarer verden gennem det fremmede sprog, og samtidig tvinges til at udtrykke sig på det. Gradvis făr man ændret en anelse ved sin synsvinkel, sin opfattelse af virkeligheden fordi det fremmede sprogs ord og begreber fremhæver noget lidt andet ved virkelighedens fænomer end ens eget sprog gør. Man tvinges til at anskue virkeligheden gennem et andet sprogs ord. Derved ændres både ens opfattelse af virkeligheden og af en selv.

Parallelt med at denne proces foregik, gjorde jeg mig megen umage med at fastholde mit danske sprog, min danske opfattelse af verden, min danske identitet.

Jeg fik efterhånden to sprog, to identiteter, og et dobbeltblik: et skarpt blik for mit eget lands goder og onder, og samtidig et lignende for det svenskes.

I sorte stunder var der ingen af dem jeg kunne holde ud, de var gennemskuet begge to! Det var som et frit fald ud i rummet, ingen værdier var faste. Jeg følte at jeg ingen steder havde hjemme. Jeg var ingen.

Efter syv år valgte jeg så mellem mine to identiteter og vendte hjem. Jeg valgte den identitet der hørte sammen med mit modersmål. Tænk, hvis jeg havde været flygtning og ikke kunne vende hjem! Så ville sagen have set helt, helt anderledes ud.

For en oversætter er den slags erfaringer uvurderlige, både de sproglige og de sociale. For det første denne stadige sammenholden af to sprog; det var 


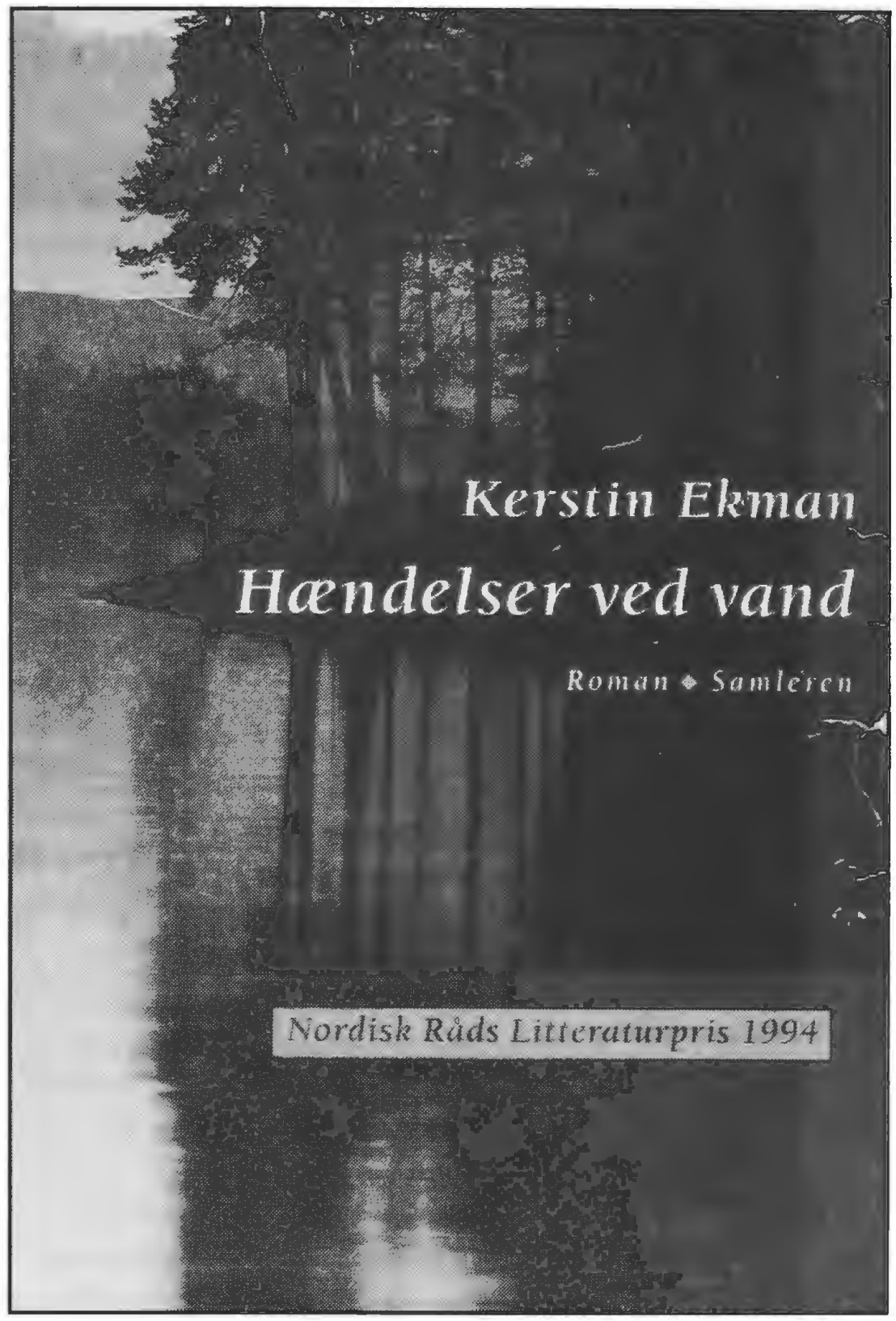

Kerstin Ekmans Hændelser ved vand er oversat af Anne Marie Bjerg efter Händelser vid vatten, 1993.

som om der hele tiden kørte to lydspor i min bevidsthed, et dansk og et svensk, og jeg oversatte til stadighed mellem dem. For det andet kendskabet til den konkrete fremmede virkelighed, og dermed begribelsen af forskellene. $\mathrm{Og}$ opgaven for en oversætter lyder: Hvordan får jeg den fremmede, in casu den svenske, virkelighed fragtet over Øresund og gjort anskuelig for danske læsere? Så den både er fuldt forståelig som netop svensk virkelighed, og samtidig udtrykt på gedigent dansk.

Det sidste forudsætter at det svenske sprog de respektive forfattere skriver, er gedigent. Og her var Per 
Wästbergs romaner en god skole at gå i: et stringent, smidigt, intellektuelt svensk; og samtidig stillede han store krav om viden, ren viden, om svenske forhold, om litteratur, kultur og historie.

I en periode havde jeg min gang på tidsskriftet Folket $i$ Bild/Kulturfront, hvor jeg var med til at bedømme noveller som folk sendte ind. Redaktionen bestilte også en føljeton hos Kerstin Ekman - det var dengang hun havde udgivet romanen Hekseringene og havde taget springet til "seriøs" forfatter. I den anledning kom jeg som Folket $i$ Bilds udsendte til Ångermanland i mellemsverige for at lave mit livs første og hidtil eneste interview. Det gik skam rigtig godt - på svensk og alting - men det skyldtes at hun godt vidste hvad hun ville fortælle. $\mathrm{Og}$ bagefter gjorde hun sig den umage en hel dag at køre mig rundt i dette storslåede landskab - det er der hvor også Skuleskoven ligger - og så at sige forære mig det og dets historie.

Også hos hende lærte jeg hvad grundig viden vil sige. Derfor ved jeg også hvad der venter af strabadser når jeg går i gang med en oversættelse af hende. Og hun ved til gengæld at jeg ikke skyr nogen anstrengelse for at finde de rigtige ord på dansk.

\section{Personligt venskab blev det til} med den græske svensker Theodor Kallifatides. I hans romaner som jeg har oversat en hel række af, fik jeg et tredje land forærende, nemlig Grækenland. Og hans svenske sprog er et af de klareste, reneste svenske jeg har oversat; det er det fordi han, der skriver på svensk, ikke har svensk som modersmål; han har måttet lære det fra grunden. Theo - som han kaldes af sine venner - viste mig den tillid at bede mig om at skrive en artikel om den danske litteratur - da jeg første gang mødte ham i hans egenskab af redaktør af Bonniers Litterära Magasin; og siden, $i$ en periode, at lade mig anmelde svensk litteratur i tidsskriftet.

Göran Tunström mødte jeg mens han endnu var forholdsvis ukendt og ikke oversat til dansk. Vi gjorde bekendtskab i et supermarked ved Slussen i Stockholm, og jeg tænkte: kan man virkelig se sådan ud når man er forfatter, han ligner jo en landsknægt fra middelalderen! Om han i virkeligheden - $\mathrm{i}$ en eller anden virkelighed - hører til i middelalderen eller i nutiden eller på Jesu tid, eller måske i en slags altid, det har jeg aldrig helt fundet ud af. Men når han slår sig løs og fortæller, mundtligt, som en Karen Blixen'sk story teller, bliver man henrykket og ved ikke hvor virkeligheden holder op og digtningen begynder. Og når jeg har skrevet og i forbindelse med oversættelsen foreholdt ham inkonsekvenser $\mathrm{i}$ hans bøger, har han sagt: Hvorfor spørger de andre oversættere ikke om det samme? Det gør kun du og så den norske og den islandske oversætter.

I Sun Axelssons romaner mødte jeg en storslået fortæller der borer dybt i sårede kvindesjæles psykologi og som formår at løfte dem over i det almene.

Agneta Pleijel har også godt fat på kvinders tilværelse og psykologi i det moderne Sverige. I hendes bøger er der et mod og en skånselsløshed som både skræmmer og lokker.

Jeg har oversat enkeltbøger af 


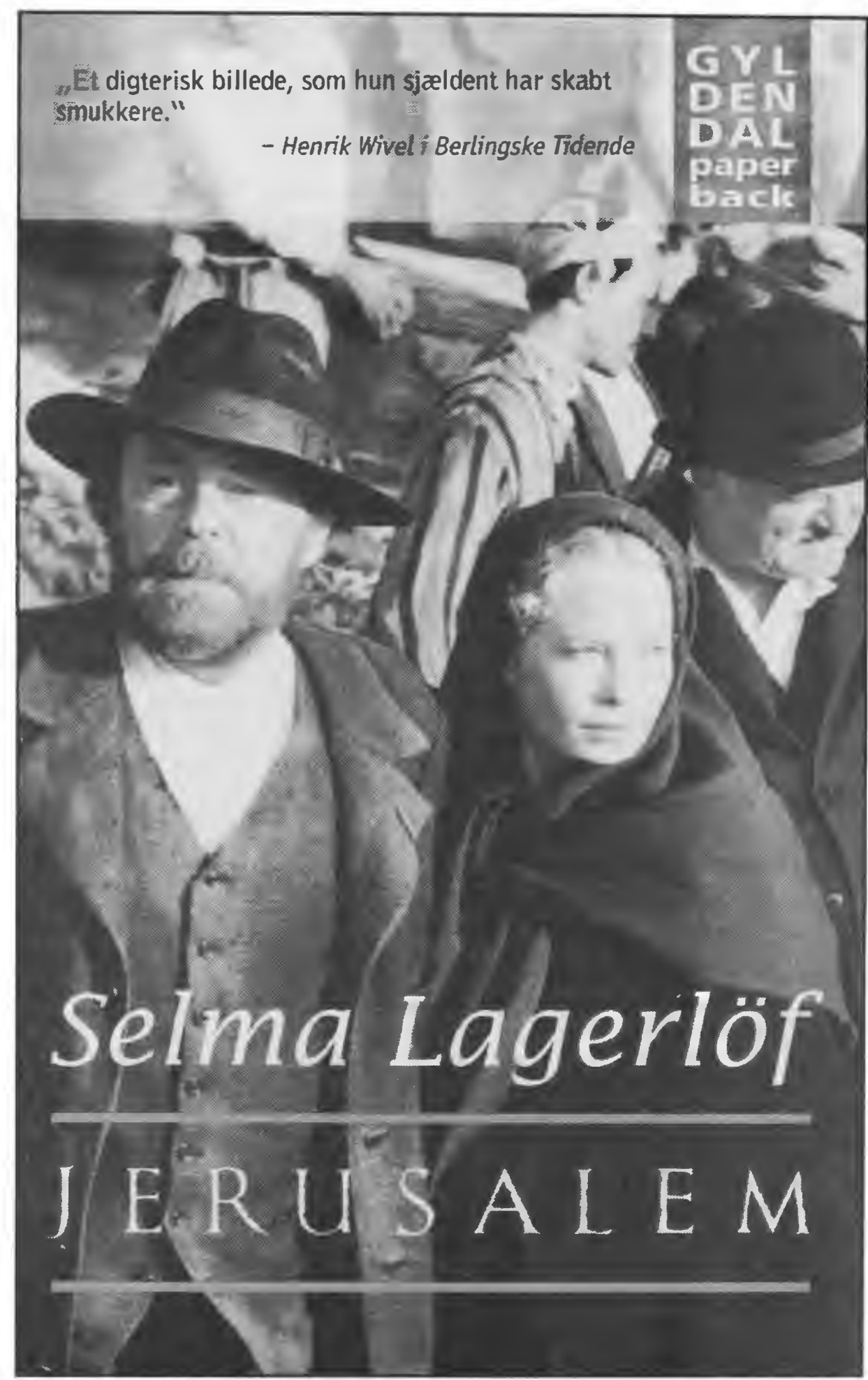

Selma Lagerlöfs Jerusalem fra 1901-02 er oversat til dansk af Anne Marie Bjerg. Bille Augusts filmatisering af romanen har givetvis medvirket til udbredelsen afforfatterskabet. 
flere forfattere: Gun-Britt Sundström, Gerda Antti, Ann-Charlotte Alverfors, Staffan Seeberg; de hører også til blandt mine svenske venskaber, selv om det er blevet ved enkelte bøger.

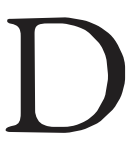
ette var nu "mine" levende svenske forfattere - gid de må skrive mange gode bøger endnu for mig at oversætte.

Men så er der de døde. Klassikerne. Elin Wagner siger ikke et dansk publikum ret meget, selv om jeg engang oversatte en rigtig god lille roman af hende, ja, lavede en radiomontage om hende. Til gengæld er hun stadig et stort navn i Sverige. Hun var journalist, pacifist, kvindelig stemmeretsforkæmper, skønlitterær forfatter, og det andet kvindelige medlem af det svenske Akademi. Hun skrev blandt andet en to-bindsbiografi over det første kvindelige akademimedlem, Selma Lagerlöf.

Og dér brænder det på for mig nu. Jeg er netop kommet hjem fra et tre ugers ophold på Gotland, på Östersjöns Forfattar- och oversättarcentrum i Visby. Der begyndte jeg på en nyoversættelse af hendes debutroman, Gösta Berlings Saga fra 1891 . Jeg har jo nyoversat Historien om familien Löwenskold og Jerusalem og Keiseren af Portugalien. Som alle klassikeroversættelser er Gösta Berlings Saga en udfordring. Hvordan skal jeg fả bogens hundrede år gamle sprog til både at være hundrede år gammelt og dog være umiddelbart forståeligt for nutidige læsere?
De afdøde forfattere kan jeg jo ikke få i tale og spørge om hvad dette og hint betyder, de må finde sig i hvad jeg kan finde på, når jeg lægger øret til og lytter. Men jeg har gået $\mathrm{i}$ en god skole hos de nulevende.

Noget af det intrikate ved at indoptage et fremmed lands forfattere og deres forfatterskaber går ud på at holde sig fri af deres indbyrdes rangorden på parnasset. Jeg forbeholder mig ret til at stå frit i forhold til hver enkelt af dem og ikke skulle foretrække den ene for den anden. Hver især er de for mig betroede opgaver. Jeg vil have lov til at solidarisere mig med hver forfatters univers uden at skulle stille dem op i et værdihierarki. Tilsammen repræsenterer de en stor rigdom, sprogligt, kunstnerisk, kulturelt.

At oversætte bøger eller hele forfatterskaber er for mig som at indgå en slags sjæleligt kærlighedsforhold: jeg holder ved forfatternes tekster i tykt og tyndt på alle deres individuelle sprogs veje og vildveje, jeg prøver ikke på at gøre dem bedre eller ringere end de er. Jeg forsøger tværtimod at være hundrede procent loyal så langt som min kunnen og viden rækker. Ingen læser så grundigt og omhyggel igt som oversætteren!

En oversætter må tage ord meget bogstaveligt, ja, en oversætter må tage ordene på ordet, eftersom det er det sted hvor virkelighed og bevidsthed mødes.

Tak for den påskønnelse for mit arbejde og min umage der ligger $\mathrm{i}$ Venskabs- og Kulturfondens pris! 